\title{
The relative importance of litter nutrients, C-related, and physical traits in controlling litter decomposition vary substantially between deciduous and evergreen species
}

\section{Zhaolin Sun ( $\nabla$ sunzlyes@163.com )}

Institute of Applied Ecology Chinese Academy of Sciences https://orcid.org/0000-0001-7332-1399

Peng Tian

Anhui Agricultural University

Xuechao Zhao

Institute of Applied Ecology Chinese Academy of Sciences

Shengen Liu

Institute of Applied Ecology Chinese Academy of Sciences

Yanping Wang

Shandong Agricultural University

Shunzhong Wang

Institute of Botany Chinese Academy of Sciences

\section{Xiangmin Fang}

Jiangxi Agricultural University

Qingkui Wang

Institute of Applied Ecology Chinese Academy of Sciences

\section{Research Article}

Keywords: Litter decomposition, litter quality, physical trait, secondary metabolite, plant functional type

Posted Date: March 2nd, 2021

DOl: https://doi.org/10.21203/rs.3.rs-217007/v1

License: (c) (1) This work is licensed under a Creative Commons Attribution 4.0 International License. Read Full License 


\section{Abstract}

Litter decomposition plays important roles in maintaining ecosystem function and controlling carbon (C) and nutrient cycle in terrestrial ecosystems. Thus, understanding its fundamental controlling factors is of great value to improve the accuracy of biologically driven global carbon (C) cycle of prediction models. In this study, we conducted a field decomposition experiment with 205 tree species litters and quantified the relative importance of litter nutrients, C-related and physical traits in controlling litter decomposition in different plant functional groups. The results showed that across all species, litter nutrients $(65.1 \%)$ explained more variation in litter decomposition than physical (17.5\%) and C-related traits (17.4\%). Litter nutrients had lower explanation for deciduous species (47.0\%) than for evergreen species $(77.9 \%)$, while C-related and physical traits had higher explanation for deciduous litters (20.5\% and $32.5 \%)$ than for evergreen species (13.5\% and $8.6 \%$ ), suggesting that the importance of these three categorized litter traits in controlling litter decomposability was plant functional type dependent. Nitrogen, tannins and water saturation capacity were the best predictors of litter decomposition among nutrients, C-related and physical traits, respectively, irrespective of plant functional types. In sum, our findings highlight the differences in the roles of initial litter nutrients, C-related and physical traits in regulating litter decomposition and suggest that litter trait-decomposition relationships vary substantially between deciduous and evergreen species, necessitating their explicit consideration in Earth's $\mathrm{C}$ cycle models to improve the accuracy of predicting litter decomposition.

\section{Introduction}

Litter decomposition is a fundamental component of terrestrial ecosystem function affecting carbon (C) and nutrient cycles (Parton et al. 2007; Swift et al. 1979; Wieder et al. 2014). The classic conceptual model generally holds that climate predominantly control on decomposition at the global scale, and litter quality at regional scale (Berg et al. 1993; Frainer et al. 2015; Wall et al. 2008). Recent studies suggest that inter-specific variation in litter quality may even play a more important role than climate in determining decomposition within biomes worldwide (Bradford et al. 2014; Cornwell et al. 2008). Hence, an advanced mechanistic understanding of the effects of litter quality on decomposition process is critical to improve our prediction of $\mathrm{C}$ and nutrient dynamic in terrestrial ecosystems.

Over the past several decades, hundreds of studies have been conducted to explore how litter quality affects litter decomposition (Frainer et al. 2015; Pichon et al. 2020; Sun et al. 2018; Swift et al. 1979), with most of them holding that initial litter nitrogen $(\mathrm{N})$ and lignin concentrations, lignin: $\mathrm{N}$ and $\mathrm{C}: \mathrm{N}$ ratios control litter decomposition (Enríquez et al. 1993; Taylor et al. 1989; Wieder et al. 2009). These studies have brought considerable advances in our understanding of litter decomposition and its underlying mechanisms. However, biogeochemical models that widely used these variables as predictor for the parameterization of litter decomposition may get inaccurate results (Adair et al. 2008; Wieder et al. 2014). First, species used in most previous studies usually ranged from several to tens, as such, the results may not be widely generalizable across multiple species. Secondly, recent evidence suggests that litter decomposition is likely influenced by a wider range of chemical traits, particularly carbon-related traits 
(e.g. polyphenol and tannins contents) than typically assumed (Glassman et al. 2018; Hättenschwiler and Bracht-Jørgensen 2010). However, most previous studies only focused on several litter chemical traits such as N, P and lignin concentrations, lignin: $\mathrm{N}$ and C:N ratios (Cornwell et al. 2008; Frainer et al. 2015; Hobbie et al. 2006; Zhou et al. 2008), likely resulting in incomplete underestimating the role of litter quality in driving litter decomposition process. Thus, conducting experiments including a wide range of chemical traits is important to improve our understanding of how litter chemical traits control litter decomposition.

Besides litter chemical traits, litter physical traits could also directly or indirectly influence the decomposition process (Chae et al. 2019; Kurokawa and Nakashizuka 2008). Several studies have focused on the role of physical traits in controlling litter decomposition, especially at the first stage of decomposition (Pakeman et al. 2011; Quested et al. 2007; Makkonen et al. 2012). They found physical traits such as specific leaf area (SLA) and water saturation were good predictors of litter decomposition, and even exerted more important roles in regulating litter decomposition than $\mathrm{N}$, lignin and $\mathrm{C} / \mathrm{N}$ ratio (Chae et al. 2019; Makkonen et al. 2012). However, most of these previous studies were based on a relatively small number of species (usually less than 10 species), such that they could not quantitatively depict the relationships of litter decomposition rates with physical traits (Canessa et al. 2020; Gartner and Cardon 2004). In addition, few studies simultaneously measured both litter chemical and physical traits, as a result that the optimal combination of litter physical and chemical traits in predicting litter decomposition remains poorly understood. In this context, the relative importance of litter nutrients, Crelated and physical traits in regulating litter decomposition have yet to be quantified.

Categorizing species into plant functional groups based on traits relating to aspects of the plant economics spectrum is a useful way to understand ecosystem processes and functions (Lin et al. 2017; Sulman et al. 2017; Zuo et al. 2018). For example, a early global synthesis demonstrated that leaf lifespan type (i.e. deciduousness) was a strong predictor of leaf decomposition, with deciduous species decomposing more rapidly than those of evergreen species (Cornwell et al. 2008). The underlying mechanism can be related to the intrinsic physicochemical variables of substrate quality from different lifespan types. For example, relative to evergreen litters, deciduous species tend to have higher nutrient concentrations (e.g. N, P), but lower lignin and phenolic compounds (Cornelissen 1996; Cornwell et al. 2008; López et al. 2001). Moreover, deciduous species are generally characterized with papery leaf and hence have lower tensile strength than the leathery-leaved evergreen species (Reich et al. 1991). These studies have clarified the difference of litter decomposition between deciduous and evergreen species, however, how leaf lifespan type mediates litter trait-decomposition relationships and the underlying mechanisms are still not well understood.

To address these knowledge gaps, we conducted a litter decomposition experiment including 205 tree species that had substantial differences in physicochemical traits using the classical litterbag method in a forest ecosystem. Species were classified into deciduous and evergreen species and 19 widely used chemical and physical variables were categorized into nutrients, C-related and physical traits. Our objectives in this study were to quantify the relative importance of nutrients, C-related and physical traits 
in regulating litter decomposition, and explore whether their relative importance differ between deciduous and evergreen species. Based on our knowledge, we hypothesized that (1) litter nutrients would be more important than C-related and physical traits in controlling litter decomposition; and (2) the relative importance of the three litter-trait categories in regulating litter decomposition and the key controlling factors would differ between deciduous and evergreen species.

\section{Materials And Methods}

\section{Study site and litter collection}

The experiment was conducted in a subtropical forest dominated by Schima superba at the Huitong Natural Research Station of Forest Ecosystem $\left(26^{\circ} 40^{\prime} \mathrm{N}, 109^{\circ} 8^{\prime} \mathrm{E}\right)$ in Hunan Province, China. The area is characterized by a humid mid-subtropical monsoon climate, with mean annual temperature of $16.5^{\circ} \mathrm{C}$ and mean annual precipitation of $1200 \mathrm{~mm}$. Monthly mean temperature ranges from $1.9^{\circ} \mathrm{C}$ in January to $29^{\circ} \mathrm{C}$ in July and $60-70 \%$ of the total precipitation occurs between April and August. The understory species are dominated by Camellia oleifera, Maesa japonica, and Ficus heteromorpha. The acid soil in the study site is classified as Oxisol according to the second edition of U.S. Soil Taxonomy.

Freshly senesced leaf litters of 205 tree species were collected in China in 2017 (Table S1). The leaf litters were collected during location-specific leaf senescence either by hand or by using litter traps. Litters with signs of herbivory or disease were discarded and then air-dried to a constant mass. These collected tree species belonged to 77 genera of 39 families and encompassed wide variation in litter traits. To examine the relationship between decomposition and plant functional types, all species were classified into deciduous and evergreen species based on leaf lifespan type. Leaf lifespan was determined based on Flora Republicae Popularis Sinicae.

\section{Litter decomposition}

The litter decomposition was carried out in the field using the classical litterbag method. An equivalent of $5 \mathrm{~g}$ dry weight of air-dried leaf litter were placed into a $15 \mathrm{~cm} \times 20 \mathrm{~cm}$ mesh nylon bag, which was constructed from polyethylene fabrics of two different mesh sizes. The bottom side of the litterbag used a small mesh size of $0.2 \times 0.2 \mathrm{~mm}$ to minimize losses of fragments, and the upper side used a large mesh size of $2 \times 2 \mathrm{~mm}$ to allow the mesofauna to freely access (Smith and Bradford 2003). In May 2018, 15 litterbags for each species were placed in the forest. In total, $3075(15 \times 205)$ litterbags were used in this experiment. The litterbags were attached to the soil surface by metal pins to prevent movement and to ensure contact between the bags and the soil layer. For each litter retrieving time, 5 litterbags (as 5 replications) for each species were randomly retrieved at 6,12 and 18 months after installation. After the collection, attached soil and in-growing roots were carefully removed from the litterbags and the remaining litter was dried at $60^{\circ} \mathrm{C}$ to constant mass, and weighed.

\section{Litter trait measurement}


The oven-dried litter samples were ground to powder using a ball mill for the chemical traits measurements and 10-20 intact leaves per species for physical traits measurements. The chemical traits included nutrients of $N$, phosphorus $(P)$, potassium $(K)$, calcium $(\mathrm{Ca})$, sodium $(\mathrm{Na})$, magnesium $(\mathrm{Mg})$, manganese (Mn), cuprum ( $\mathrm{Cu})$, zinc ( $\mathrm{Zn})$, and the carbon-related traits of lignin, cellulose, hemicellulose, total phenols, soluble phenols, non-structural carbohydrates (NSC), and tannins. The physical traits included SLA, water saturation capacity, and tensile strength. The detail descriptions of methods used for the measurements of each litter trait were shown in Table S2 .

\subsection{Statistical analysis}

The decomposition constants ( $k$ values in units of year ${ }^{-1}$ ) were calculated by fitting the first-order exponential decay function (Olson 1963):

$y=e^{-k t}$

where $y$ is the percent of litter dry mass remaining in litterbags at time $t$ (year) and $k$ is the decomposition constant.

The significant differences of litter physicochemical traits and $k$-value between different lifespan types were tested by separate two-tailed Wilcoxon rank sum tests. The relationships between litter physicochemical traits and $k$-value were tested by regression analysis. In cases where the data did not conform to the assumptions of normality, In-transformations were applied before analysis. Principal component analysis (PCA) was conducted with $k$-value and litter traits for all species and species with different lifespan type.

We used ordinary least squares (OLS) multiple regression models to examine the effects of litter traits on $k$-value. Before performing the analysis, all litter traits along with $k$-value were standardized (average $=0$ and $S D=1$ ) to eliminate unit dimension effects. We also calculated variance inflation factor (VIF) to evaluate the collinearity of the variables within our multiple regression models using the CAR package in $\mathrm{R}$ (Table S3). Collinearity between variables is considered to be significant when VIF is greater than three (Chen et al. 2019). The best model was selected using corrected Akaike information criterion (AICC) by considering the lowest AICc (Burnham and Anderson 2002). This model selection procedure was performed using the function 'dredge' in the R package MuMIn (Bartoń 2016). Hierarchical partitioning analyses were further performed to disentangle the relative importance of each trait and the three trait categories (nutrients, C-related and physical traits) in the final multiple regression models for all species and species with different lifespan type using the HIER.PART package in R (Walsh and Nally 2013). All the statistical analyses were conducted in R 3.5.1.

\section{Results}

\section{Variations in initial litter traits and decomposition rate}


Initial litter traits varied substantially across all the species and had more than $80 \%$ traits exhibiting over 10-fold variations (Table 1). Deciduous litters had significantly higher concentrations of $\mathrm{N}, \mathrm{P}, \mathrm{K}, \mathrm{Ca}, \mathrm{Mg}$ and $\mathrm{Cu}, \mathrm{SLA}$ and water saturation than evergreen litters, but lower Mn concentration, $\mathrm{C}: \mathrm{N}$ and lignin: $\mathrm{N}$ ratios and tensile strength (Table S4). 
Table 1

Summary of decomposition rate constants ( $k$-value), traits and key ratios of leaf litters for 205 tree species.

\begin{tabular}{|c|c|c|c|c|}
\hline Traits & Minimum & Maximum & Mean & CV (\%) \\
\hline$k$-value & 0.43 & 4.36 & 1.54 & 50 \\
\hline $\mathrm{N}\left(\mathrm{mg} \mathrm{g}^{-1}\right)$ & 5.18 & 57.46 & 22.48 & 42 \\
\hline$P\left(\mathrm{mg} \mathrm{g}^{-1}\right)$ & 0.38 & 5.81 & 1.59 & 59 \\
\hline $\mathrm{K}\left(\mathrm{mg} \mathrm{g}^{-1}\right)$ & 1.04 & 31.50 & 11.98 & 49 \\
\hline $\mathrm{Ca}\left(\mathrm{mg} \mathrm{g}^{-1}\right)$ & 1.09 & 41.58 & 14.22 & 67 \\
\hline $\mathrm{Na}\left(\mathrm{mg} \mathrm{g}^{-1}\right)$ & 0.01 & 0.70 & 0.07 & 122 \\
\hline $\operatorname{Mg}\left(\mathrm{mg} \mathrm{g}^{-1}\right)$ & 0.47 & 8.60 & 2.42 & 48 \\
\hline $\mathrm{Mn}\left(\mathrm{mg} \mathrm{g}^{-1}\right)$ & 0.01 & 3.83 & 0.50 & 129 \\
\hline $\mathrm{Cu}\left(\mathrm{mg} \mathrm{g}^{-1}\right)$ & 0.00 & 0.03 & 0.01 & 80 \\
\hline $\mathrm{Zn}\left(\mathrm{mg} \mathrm{g}^{-1}\right)$ & 0.01 & 0.33 & 0.04 & 114 \\
\hline NSC ( \%) & 1.84 & 9.79 & 4.73 & 33 \\
\hline Lignin (\%) & 2.62 & 27.79 & 10.03 & 44 \\
\hline Cellulose (\%) & 12.06 & 38.63 & 25.27 & 23 \\
\hline Hemicellulose (\%) & 1.66 & 48.48 & 20.73 & 44 \\
\hline Soluble phenols (\%) & 0.25 & 14.15 & 3.69 & 77 \\
\hline Phenols (\%) & 0.60 & 14.15 & 4.93 & 63 \\
\hline Tannins (\%) & 0.43 & 17.95 & 2.49 & 104 \\
\hline $\operatorname{SLA}\left(\mathrm{mm}^{2} \mathrm{mg}^{-1}\right)$ & 3.20 & 42.17 & 16.12 & 44 \\
\hline Saturation (\%) & 70.18 & 482.31 & 168.34 & 34 \\
\hline Tensile ( $\mathrm{N} \mathrm{cm}^{-1}$ width) & 0.73 & 123.00 & 8.83 & 183 \\
\hline $\mathrm{C}: \mathrm{N}$ & 7.88 & 97.65 & 25.74 & 48 \\
\hline Lignin:N & 0.72 & 19.03 & 5.49 & 62 \\
\hline
\end{tabular}


Leaf litters displayed an average mass loss of $84.1 \%$ with a range from 45.9-99.2\% across all 205 species, and deciduous species (90.4\%) had higher mass loss than evergreen species $(77.0 \%)$ at the end of 1.5-year decomposition (Fig. S1). Accordingly, $k$-value exhibited a large variation across different species with the mean of $1.54 \mathrm{yr}^{-1}$ and the range of $0.43-4.36 \mathrm{yr}^{-1}$ (Fig. 1, Table S1). The mean $k$-value of deciduous litters $\left(1.88 \pm 0.05 \mathrm{yr}^{-1}\right)$ was significantly higher than that of evergreen litters $(1.16 \pm 0.07$ $\left.\mathrm{yr}^{-1}\right)$.

\section{Controlling factors of litter decomposition and their relative importance}

Across the 205 species, $k$-value was positively related to initial concentrations of $\mathrm{N}, \mathrm{P}, \mathrm{K}, \mathrm{Ca}, \mathrm{Mg}, \mathrm{Cu}, \mathrm{Zn}$, cellulose, water saturation and SLA, but negatively related to $\mathrm{Mn}$, tannins, tensile strength, C:N and lignin: $\mathrm{N}$ ratios (Table S5). $k$-value was correlated positively with initial concentrations of $\mathrm{N}, \mathrm{P}, \mathrm{K}, \mathrm{Mg}, \mathrm{Cu}$, water saturation capacity and SLA and correlated negatively with tannins, tensile strength, C:N and lignin: $\mathrm{N}$ ratios for both deciduous and evergreen species (Fig. 2, Table S5). In addition, $k$-value was positively correlated with $\mathrm{Ca}$ and $\mathrm{Zn}$ concentrations in evergreen species, but not in deciduous species.

According to the PCA analysis results, $k$-value and litter traits for all species captured $27.3 \%$ and $12.3 \%$ of the total variation explained by the first and second axes, respectively (Fig. 3a). The first PCA axis was correlated positively with $k$-value, N, P, K and SLA. The second PCA axis was negatively correlated with lignin, soluble phenols and total phenols. The final OLS multiple regression model showed that approximately $62.4 \%$ of the total variation of k-value could be explained by a set of litter traits including $\mathrm{N}, \mathrm{Ca}, \mathrm{Mg}$, tannins, NSC, lignin, water saturation capacity and tensile strength (Tables S6 and S7). Through further hierarchical partitioning analyses, the relative importance in regulating $k$-value was ranked as nutrients (N:39.7\%, Mg:14.4\%, Ca:11.0\%), C-related traits (tannins:13.2\%, NSC:2.7\%, lignin:1.5\%), and physical traits (water saturation capacity:9.7\%, tensile strength:7.7\%) at $65.1 \%, 17.5 . \%$ and $17.4 \%$, respectively (Fig. 4 , Table 2 ). 
Table 2

Individual contribution rate of each trait and cumulative contribution rate of different categories (highlighted in bold) in decomposition rate constants ( $k$-value) for all species and species with different lifespan type.

\begin{tabular}{|llll|}
\hline Traits & All & Deciduous & Evergreen \\
\hline $\mathrm{N}$ & 39.77 & 33.27 & 42.36 \\
\hline $\mathrm{Ca}$ & 11.04 & 5.43 & 27.46 \\
\hline $\mathrm{Mg}$ & 14.39 & 8.35 & 8.11 \\
\hline $\mathrm{Zn}$ & & & 77.93 \\
\hline Nutrients & 65.20 & 47.05 & 3.48 \\
\hline NSC & 2.71 & 2.74 & 1.70 \\
\hline Lignin & 1.49 & 1.78 & 8.32 \\
\hline Soluble phenols & & & 13.50 \\
\hline Tannins & 13.23 & 15.95 & 8.57 \\
\hline C-related & 17.43 & 20.47 & 8.57 \\
\hline Saturation & 9.71 & 17.11 & 100 \\
\hline Tensile & 7.66 & 15.37 & \\
\hline Physical & 17.67 & 32.48 & 100 \\
\hline Total & 100 & & \\
\hline N, nitrogen; Ca, calcium; Mg, magnesium; Zn, zinc; NSC, non-structural carbohydrates. & \\
\hline
\end{tabular}

The first two axes of the PCA accounted for $34.8 \%$ of the variation in the deciduous species (Fig. $3 \mathrm{~b}$ ) and $38.7 \%$ in the evergreen species (Fig. 3c). In the optimal OLS multiple regression model (Tables S6 and S7), N, Ca, Mg, tannins, NSC, lignin, water saturation capacity and tensile strength could explain $56.8 \%$ of the variance in $k$-value of deciduous species, while $\mathrm{N}, \mathrm{Ca}, \mathrm{Zn}$, tannins, NSC, soluble phenols and water saturation capacity could explain $56.3 \%$ of the variance in $k$-value of evergreen species. Based on the hierarchical partitioning analyses, we found that the relative importance of nutrients in predicting $k$-value was lower for deciduous species (47.0\%) than for evergreen species $(77.9 \%)$, but C-related and especially physical traits were higher for deciduous species $(20.5 \%$ and $32.5 \%$, respectively) than for evergreen species (13.5\% and $8.6 \%$, respectively; Fig. 4 , Table 2$)$. However, regardless of plant functional types, $N$ (33.3\% for deciduous species and $42.4 \%$ for evergreen species), tannins ( $16.0 \%$ for deciduous species and $8.3 \%$ for evergreen species) and water saturation capacity $(17.1 \%$ for deciduous species and $8.6 \%$ for evergreen species) were the best predictors among nutrients, C-related and physical traits, respectively (Table 2). 


\section{Discussion}

Compared with previous studies with a small number of litter species (Hobbie et al. 2006; Makkonen et al. 2012; Mao et al. 2018), we used 205 litter species with 108 deciduous and 97 evergreen species in field decomposition and simultaneously measured 19 widely used physicochemical traits to explore how litter traits control litter decomposition. Thus, we considered our results may get a more robust picture of the litter trait-decomposition linkages than previous studies. Our results showed that all of litter nutrients, Crelated, and physical traits can be used to predict litter decomposition, but their relative importance for litter decomposition varied substantially between deciduous and evergreen species. Therefore, these findings have somewhat improved our understanding of how litter traits regulate litter decomposition in terrestrial ecosystems.

\section{Importance of initial litter traits in controlling decomposition across all species}

Across all species, the mean litter decomposition rate of $1.53 \mathrm{yr}^{-1}$ with a range from $0.43 \mathrm{yr}^{-1}$ to $4.36 \mathrm{yr}^{-}$

1 (Table 1, Fig. 1) is within the range reported by most previous studies (Keller and Phillips 2019; Makkonen et al. 2012; Zhang et al. 2016). This substantial variation in litter decomposition rates coincided well with the large differences in litter traits including nutrients, C-related and physical traits (Table 1). As our first hypothesis, nutrients accounted for larger variation in litter decomposition than physical and C-related traits (Fig. 4), which is consistent with the general opinion that the community structure and activities of decomposer organisms are predominantly constrained by the availability of macronutrients (Hättenschwiler et al. 2011; Silver and Miya 2001; Swift et al. 1979). Among all selected nutrients, the relative importance of $\mathrm{N}$ concentration for litter decomposition was much higher than $\mathrm{Ca}$ and/or Mg (Table 2, Fig. 2a-c), contradicting some previous studies reporting that Ca (Reich et al. 2005) and $\mathrm{Mg}$ (Makkonen et al. 2012; Vivanco and Austin 2019) were the best predictors of litter decomposability. We speculate that this discrepancy could be attributed to the huge difference in the number of species included in past and our study (10-16 vs. 205 , respectively), because relationships between litter traits and litter decomposition rates can vary with the sample size used in the analyses (Canessa e t al. 2020).

Consistent with previous studies (Chomel et al. 2016; Hättenschwiler and Vitousek 2000), C-related traits were clearly important determinants of litter decomposition rates, which contributed $17.4 \%$ of the relative importance in predicting litter decomposition (Fig. 4). Specifically, tannins, an important component of secondary metabolites, stood out as best predictor of litter decomposition among C-related traits rather than the commonly recognized lignin (Austin and Ballaréet 2010; Cornwell et al. 2008). The negative relation of tannins concentrations to litter decomposition (Fig. 2d) is in agreement with some previous observations within and between ecosystems (Chomel et al. 2014; Kraus et al. 2004; Makkonen et al. 2012), suggesting that tannins inhibits litter decomposition. This inhibitory effect has been ascribed to the toxic effects of tannins on microbial metabolism and digestive enzymes during the decomposition process (Coq et al. 2010). For example, Triebwasser et al. (2012) reported that the addition of tannins extracted from senescing leaves significantly inhibited the potential activity of enzymes. Our results 
indicate that tannins may slow down $\mathrm{C}$ and nutrient cycling by decreasing litter decomposition, and consequently contribute to soil $\mathrm{C}$ sequestration in forest ecosystems. Therefore, our findings contribute to growing support for the argument of considering secondary compounds as key drivers of ecosystem functioning (Chomel et al. 2016).

We observed that litter decomposition exhibited a positive correlation with water saturation capacity (Fig. 2e) and a negative correlation with tensile strength (Fig. 2f), suggesting that litter physical traits play important roles in controlling litter decomposition. Our findings confirm some previous observations (Chae et al. 2019; Cornelissen et al. 1999; Makkonen et al. 2012). Furthermore, we found that water saturation capacity was the best physical predictor and contributed $9.7 \%$ relative importance for litter decomposition (Table 2). The positive effect of water saturation capacity on litter decomposition could be linked to its role in creating a favorable microenvironment as it closely associates with water acquisition and retention, thereby favouring long-term microbial growth and activity (Makkonen et al. 2012, 2013).

\section{Differences in the underlying mechanisms of litter decomposition between evergreen and deciduous species}

Confirming our second hypothesis, litter trait-decomposition linkages were mediated by lifespan type, showing that deciduous species was primarily regulated by both nutrients and physical traits, whereas evergreen species were mostly explained by nutrients alone (Fig. 4). These results indicate that the mechanisms governing leaf litter decomposition are functional type dependent. Therefore, plant functional types must be taken into consideration in $\mathrm{C}$ cycle models when predicting litter decomposition.

Consistent with the pattern observed in all species, nutrients explained the highest variation of litter decomposition in both deciduous and evergreen species, but its explanatory power was lower for deciduous species than evergreen species (Fig. 4). This finding could be largely due to the distinct initial nutrient concentrations between these two functional types. Indeed, deciduous litters contained higher nutrient concentrations (e.g. N, Ca, Mg) than that in evergreen litters (Table S4), and thus more suitable for decomposers growth and reproduction (Cornwell et al. 2008; López et al. 2001). That is to say, decomposer organisms breaking down deciduous litters might be less restricted by nutrient availability compared to evergreen litters. Consequently, litter decomposition in evergreen species was more susceptible to initial nutrient concentrations. In contrast, the relative importance of physical traits for litter decomposition were more than 3 times higher in deciduous species than evergreen species (Table 2). This result is reasonable, because decomposer activity will be more affected by abiotic factors when nutrient limitation diminished (Bradford et al. 2016). Therefore, physical traits that strongly control the microclimate (e.g. moisture) for decomposers as discussed above, may play more important roles in regulating litter decomposition in deciduous litters, especially during the drier months (Cornelissen et al. 1999; Makkonen et al. 2012).

Although the relative importance of nutrients, C-related and physical traits differed between deciduous and evergreen species, the best predictors of litter decomposition among the three trait categories were 
the same (i.e. N, tannins and water saturation, Table 2). This finding may suggest that the major controlling factors of litter decomposition are inherent irrespective of the identity of plant functional types, which will facilitate the simplification of global carbon cycling models. However, we still found some particular traits (e.g. Zn and soluble phenols) in predicting litter decomposition between these two functional types. The reason for this finding could be that the diversity of microbial community, especially the relative abundance of specific taxa that are involved in the decomposition process might differ between deciduous and evergreen species (Li et al. 2019).

\section{Conclusions}

This study quantified the differences in the relative importance of nutrients, C-related and physical traits in controlling litter decomposition, and the litter trait-decomposition relationships between different plant functional types. Results showed that initial litter nutrients exerted more important control on litter decomposition than physical and C-related traits. In particular, this study found for the first that the underlining mechanisms governing leaf litter decomposition are functional type dependent, as nutrients and physical traits jointly played controlling roles in deciduous species, whereas nutrients alone dominated in evergreen species. Nitrogen, tannins and water saturation were the best predictors of litter decomposition among nutrients, C-related and physical traits, respectively, regardless of plant functional types. Our results suggest that considering not only litter nutrients, C-related and physical traits but also plant functional types will improve the accuracy of predicting the litter decomposition as an important component of global biosphere-atmosphere $\mathrm{C}$ fluxes in Earth's $\mathrm{C}$ cycle models.

\section{Declarations}

\section{Acknowledgement}

This work was supported by the National Natural Science Foundation of China (grant No. 31830015), the National Key Research and Development Program of China (grant No. 2016YFA0600801) and Key projects of Jiangxi Science and Technology Program (grant No. 20181ACF60011). We are grateful to Youzhi Yu, Fuming Xiao, Ke Huang, Tao Sun and Renhui Miao for their helps during collecting litters.

\section{Author contribution statement}

QKW, ZLS formulated the idea; QKW, ZLS, PT, and SEL designed the methodology; ZLS, XCZ, SEL, YPW, SZW, and XMW conducted fieldwork; ZLS and SEL analyzed the data; QZLS and QKW wrote the manuscript.

\section{Compliance with ethical standards}

Conflict of interest The authors declare that they have no confict of interest.

\section{References}


1. Adair EC, Parton WJ, Del Grosso SJ, Silver WL, Harmon ME, Hall SA, Burke IC, Hart SC (2008) Simple three-pool model accurately describes patterns of long term litter decomposition in diverse climates. Glob Chang Biol 14:2636-2660. https://doi.org/10.1111/j.1365-2486.2008.01674.x

2. Austin AT, Ballaré CL (2010) Dual role of lignin in plant litter decomposition in terrestrial ecosystems. P NAS 107:4618-4622. https://doi.org/10.1073/pnas.0909396107

3. Bartoń K (2016) MuMIn: Multi-model inference. R package version 1.15.6. Retrieved from https://CRAN.R-project.org/package=MuMln

4. Berg B, Berg MP, Bottner P, Box E, Breymeyer A, Ca de Anta R, Couteaux M, Escudero A, Gallardo A, Kratz W, Madeira M, Mälkönen E, McClaugherty C, Meentemeyer V, Muñoz F, Piussi P, Remacle J, Vi de Santo A (1993) Litter mass loss in pine forests of Europe and Eastern United States: some relationships with climate and litter quality. Biogeochemistry 20:127-153

5. Bradford MA, Berg B, Maynard DS, Wieder WR, Wood SA (2016) Understanding the dominant controls on litter decomposition. J Ecol 104:229-238. https://doi.org/10.1111/1365-2745.12507

6. Bradford MA, Warren IIRJ, Baldrian P, Crowther TW, Maynard DS, Oldfield EE, Wieder WR, Wood SA, King JR (2014) Climate fails to predict wood decomposition at regional scales. Nat Clim Change 4:625-630. https://doi.org/10.1038/nclimate2251

7. Burnham KP, Anderson DR (2002) Model selection and multimodel inference: A practical information-theoretic approach. Springer-Verlag, New York

8. Canessa R, van den Brink L, Saldaña A, Rios RS, Hättenschwiller S, Mueller CW, Prater I, Tielbörger K, Bader MY (2020) Relative effects of climate and litter traits on decomposition change with time, climate and trait variability. J Ecol 00:1-12. https://doi.org/10.1111/1365-2745.13516

9. Chae HM, Choi SH, Leem SH, Cha S, Yang KC, Shim JK (2019) Effect of litter quality on needle decomposition for four pine species in Korea. Forests 10:371. https://doi.org/10.3390/f10050371

10. Chen L, Xiang W, Wu H, Ouyang S, Zhou BO, Zeng Y, Chen YL, Kuzyakov Y (2019) Tree species identity surpasses richness in affecting soil microbial richness and community composition in subtropical forests. Soil Biol Biochem 130:113-121. https://doi.org/10.1016/j.soilbio.2018.12.008

11. Chomel M, Fernandez C, Bousquet-Melou A, Gers C, Monnier Y, Santonja M, Gauquelin T, Gros R, Lecareux C, Baldy V (2014) Secondary metabolites of Pinus halepensis alter decomposer organisms and litter decomposition during afforestation of abandoned agricultural zones. J Ecol 102:411-424. https://doi.org/10.1111/1365-2745.12205

12. Chomel M, Guittonny-Larcheveque M, Fernandez C, Gallet C, DesRochers A, Paré D, Jackson BG, Baldy V (2016) Plant secondary metabolites: a key driver of litter decomposition and soil nutrient cycling. J Ecol 104:1527-1541. https://doi.org/10.1111/1365-2745.12644

13. Coq S, Souquet JM, Meudec E, Cheynier V, Hättenschwiler S (2010) Interspecific variation in leaf litter tannins drives decomposition in a tropical rain forest of French Guiana. Ecology 91:2080-2091. https://doi.org/10.1890/09-1076.1

14. Cornelissen JHC (1996) An experimental comparison of leaf decomposition rates in a wide range of temperate plant species and types. J Ecol 84:573-582. https://doi.org/10.2307/2261479 
15. Cornelissen JHC, Perez-harguindeguy N, Díaz S, Grime JP, Marzano B, Cabido M, Vendramini F, Cerabolini $B$ (1999) Leaf structure and defence control litter decomposition rate across species and life forms in regional floras on two continents. New Phytol 143:191-200. https://doi.org/10.1046/j.1469-8137.1999.00430.x

16. Cornwell WK, Cornelissen JHC, Amatangelo K, Dorrepaal E, Eviner VT, Godoy O, Hobbie SE (2008) Plant species traits are the predominant control on litter decomposition rates within biomes worldwide. Ecol Lett 11:1065-1071. https://doi.org/10.1111/j.1461-0248.2008.01219.x

17. Enríquez S, Duarte CM, Sand-Jensen K (1993) Patterns in decomposition rates among photosynthetic organisms: the importance of detritus C:N:P content. Oecologia 94:457-471. https://doi.org/10.1007/BF00566960

18. Frainer A, Moretti MS, Xu W, Gessner MO (2015) No evidence for leaf-trait dissimilarity effects on litter decomposition, fungal decomposers, and nutrient dynamics. Ecology 96:550-561. https://doi.org/10.1890/14-1151.1

19. Gartner TB, Cardon ZG (2004) Decomposition dynamics in mixed-species leaf litter. Oikos 104:230246. https://doi.org/10.1111/j.0030-1299.2004.12738.x

20. Glassman SI, Weihe C, Li JH, Albright MBN, Looby Cl, Martiny AC, Treseder KK, Allison SD, Martiny JBH (2018) Decomposition responses to climate depend on microbial community composition. PNAS 115:11994-11999. https://doi.org/10.1073/pnas.1811269115

21. Hättenschwiler S, Bracht-Jørgensen H (2010) Carbon quality rather than stoichiometry controls litter decomposition in a tropical rain forest. J Ecol 98:754-763. https://doi.org/10.1111/j.13652745.2010.01671.x

22. Hättenschwiler S, Coq S, Barantal S, Handa IT (2011) Leaf traits and decomposition in tropical rainforests: revisiting some commonly held views and towards a new hypothesis. New Phytol 189:950-965. https://doi.org/10.1111/j.1469-8137.2010.03483.x

23. Hättenschwiler S, Vitousek PM (2000) The role of polyphenols in terrestrial ecosystem nutrient cycling. Trends Ecol Evol 15:238-243. https://doi.org/10.1016/S0169-5347(00)01861-9

24. Hobbie SE, Reich PB, Oleksyn J, Ogdahl M, Zytkowiak R, Hale C, Karolewski P (2006) Tree species effects on decomposition and forest floor dynamics in a common garden. Ecology 87:2288-2297. https://doi.org/10.1890/0012-9658

25. Hobbie SE, Eddy WC, Buyarski CR, Adair EC, Ogdahl ML, Weisenhorn P (2012) Response of decomposing litter and its microbial community to multiple forms of nitrogen enrichment. Ecol Monogr 82:389-405. https://doi.org/10.1890/11-1600.1

26. Keller AB, Phillips RP (2019) Leaf litter decay rates differ between mycorrhizal groups in temperate, but not tropical, forests. New Phytol 222:556-564. https://doi.org/10.1111/nph.15524

27. Kurokawa H, Nakashizuka $\mathrm{T}$ (2008) Leaf herbivory and decomposability in a Malaysian tropical rain forest. Ecology 89:2645-2656. https://doi.org/10.1890/07-1352.1

28. Li YB, Bezemer TM, Yang JJ, Lü XT, Li XY, Liang WJ, Han XG, Li Q (2019) Changes in litter quality induced by $\mathrm{N}$ deposition alter soil microbial communities. Soil Biol Biochem 130:33-42. 
https://doi.org/10.1016/j.soilbio.2018.11.025

29. Lin GG, McCormack ML, Ma CG, Guo DL (2017) Similar below-ground carbon cycling dynamics but contrasting modes of nitrogen cycling between arbuscular mycorrhizal and ectomycorrhizal forests. New Phytol 213:1440-1451. https://doi.org/10.1111/nph.14206

30. López ES, Pardo I, Felpeto N (2001) Seasonal differences in green leaf breakdown and nutrient content of deciduous and evergreen tree species and grass in a granitic headwater stream. Hydrobiologia 464:51-61. https://doi.org/10.1023/A:1013903500888

31. Makkonen M, Berg MP, Handa IT, Hättenschwiler S, van Ruijven J, van Bodegom PM, Aerts R (2012) Highly consistent effects of plant litter identity and functional traits on decomposition across a latitudinal gradient. Ecol Lett 15:1033-1041. https://doi.org/10.1111/j.1461-0248.2012.01826.x

32. Makkonen M, Berg MP, van Logtestijn RSP, van Hal JR, Aerts R (2013) Do physical plant litter traits explain non-additivity in litter mixtures? A test of the improved microenvironmental conditions theory. Oikos 122:987-997. https://doi.org/10.1111/j.1600-0706.2012.20750.x

33. Mao R, Zhang XH, Song CC, Wang XW, Finnegan PM (2018) Plant functional group controls litter decomposition rate and its temperature sensitivity: An incubation experiment on litters from a boreal peatland in northeast China. Sci Total Environ 626:678-683.

https://doi.org/10.1016/j.scitotenv.2018.01.162

34. Olson JS (1963) Energy storage and the balance of producters and the decomposers in ecological systems. Ecology 14:322-331

35. Pakeman RJ, Eastwood A, Scobie A (2011) Leaf dry matter content as a predictor of grassland litter decomposition: a test of the 'mass ratio hypothesis'. Plant Soil 342:49-57. https://doi.org/10.1007/s11104-010-0664-z

36. Parton W, Silver WL, Burke IC, Grassens L, Harmon ME, Currie WS, King JY, Adair EC, Brandt LA, Hart SC, Fasth B (2007) Global-scale similarities in nitrogen release patterns during long-term decomposition. Science 315:361-364. https://doi.org/10.1126/science.1134853

37. Pichon NA, Cappelli SL, Soliveres S, Hölzel N, Klaus VH, Kleinebecker T, Allan E (2020) Decomposition disentangled: $A$ test of the multiple mechanisms by which nitrogen enrichment alters litter decomposition. Funct Ecol 34:1485-1496. https://doi.org/10.1111/1365-2435.13560

38. Quested H, Eriksson O, Fortunel C, Garnier E (2007) Plant traits relate to whole-community litter quality and decomposition following land use change. Funct Ecol 21:1016-1026. https://doi.org/10.2307/20142742

39. Reich PB, Oleksyn J, Modrzynski J, Mrozinski P, Hobbie SE, Eissenstat DM, Chorover J, Chadwick OA, Hale CM, Tjoelker MG (2005) Linking litter calcium, earthworms and soil properties: a common garden test with 14 tree species. Ecol Lett 8:811-818. https://doi.org/10.1111/j.14610248.2005.00779.x

40. Reich PB, Uhl C, Waiters MB, Ellsworth DS (1991) Leaf lifespan as a determinant of leaf structure and function among 23 amazonian tree species. Oecologia 86:16-24.

https://doi.org/10.1007/BF00317383

Page 15/20 
41. Silver WL, Miya RK (2001) Global patterns in root decomposition: comparisons of climate and litter quality effects. Oecologia 129:407-419. https://doi.org/10.1007/s004420100740

42. Smith VC, Bradford MA (2003) Litter quality impacts on grassland litter decomposition are differently dependent on soil fauna across time. Appl Soil Ecol 24:197-203. https://doi.org/10.1016/S09291393(03)00094-5

43. Sulman BN, Brzostek ER, Medici C, Shevliakova E, Menge DNL, Phillips RP (2017) Feedbacks between plant $\mathrm{N}$ demand and rhizosphere priming depend on type of mycorrhizal association. Ecol Lett 20:1043-1053. https://doi.org/10.1111/ele.12802

44. Sun T, Hobbie SE, Berg B, Zhang HG, Wang QK, Wang ZW, Hättenschwiler S (2018) Contrasting dynamics and trait controls in first-order root compared with leaf litter decomposition. P NAS 115:10392-10397. https://doi.org/10.1073/pnas.1716595115

45. Swift JM, Heal OW, Anderson JM (1979) Decomposition in Terrestrial Ecosystems. University of California Press, Berkeley

46. Taylor BR, Parkinson D, Parsons WFJ (1989) Nitrogen and lignin content as predictors of litter decay rates: a microcosm test. Ecology 70:97-104. https://doi.org/10.2307/1938416

47. Triebwasser DJ, Tharayil N, Preston CM, Gerard PD (2012) The susceptibility of soil enzymes to inhibition by leaf litter tannins is dependent on the tannin chemistry, enzyme class and vegetation history. New Phytol 196:1122-1132. https://doi.org/10.1111/j.1469-8137.2012.04333.x

48. Vivanco L, Austin AT (2019) The importance of macro- and micro-nutrients over climate for leaf litter decomposition and nutrient release in Patagonian temperate forests. Forest Ecol Manag 441:144154. https://doi.org/10.1016/j.foreco.2019.03.019

49. Wall DH, Bradford MA, St. John MG, Trofymow JA, Behan-Pelletier V, Bignell DE, Dangerfield JM, Parton WJ, Rusek J, Voigt W, Wolters V, Gardel HZ, Ayuke FO, Bashford R, Beljakova OI, Bohlen PJ, Brauman A, Flemming S, Henschel JR, Johnson DL, Jones TH, Kovarova M, Kranabetter JM, Kutny L, Lin KC, Maryati M, Masse D, Pokarzhevskii A, Rahman H, Sabará MG, Salamon JA, Swift MJ, Varela A, Vasconcelos HL, White D, Zou XM (2008) Global decomposition experiment shows soil animal impacts on decomposition are climate-dependent. Glob Chang Biol 14: 2661-2677. https://doi.org/ 10.1111/j.1365-2486.2008.01672.x

50. Walsh C, Nally RM (2013) hier.part: Hierarchical partitioning. Retrieved from https://cran.r-project.org /web/packages/hier.part/ index.html

51. Wieder WR, Cleveland CC, Townsend AR (2009) Controls over leaf litter decomposition in wet tropical forests. Ecology 90: 3333-3341. https:// doi.org/ 10.1890/08-2294.1

52. Wieder WR, Boehnert J, Bonan GB (2014) Evaluating soil biogeochemistry parameterizations in Earth system models with observations. Glob Biogeochem Cy 28: 211-222. https://doi.org/ 10.1002/2013GB004665

53. Zhang WD, Chao L, Yang QP, Wang QK, Fang YT, Wang SL (2016) Litter quality mediated nitrogen effect on plant litter decomposition regardless of soil fauna presence. Ecology 97: 2834-2843. https://doi.org/ 10.1002/ecy.1515 
54. Zhou GY, Guan LL, Wei XH, Tang XL, Liu SG, Liu JX, Zhang DQ, Yan JH (2008) Factors influencing leaf litter decomposition: an intersite decomposition experiment across China. Plant Soil 311:61-72. https://doi.org/10.1007/s11104-008-9658-5

55. Zuo J, Hefting MM, Berg MP, van Logtestijn RSP, van Hal J, Goudzwaard L, Liu JC, Sass-Klaassen U, Sterck FJ, Poorter L, Cornelissen JHC (2018) Is there a tree economics spectrum of decomposability? Soil Biol Biochem 119:135-142. https://doi.org/10.1016/j.soilbio.2018.01.019

\section{Figures}

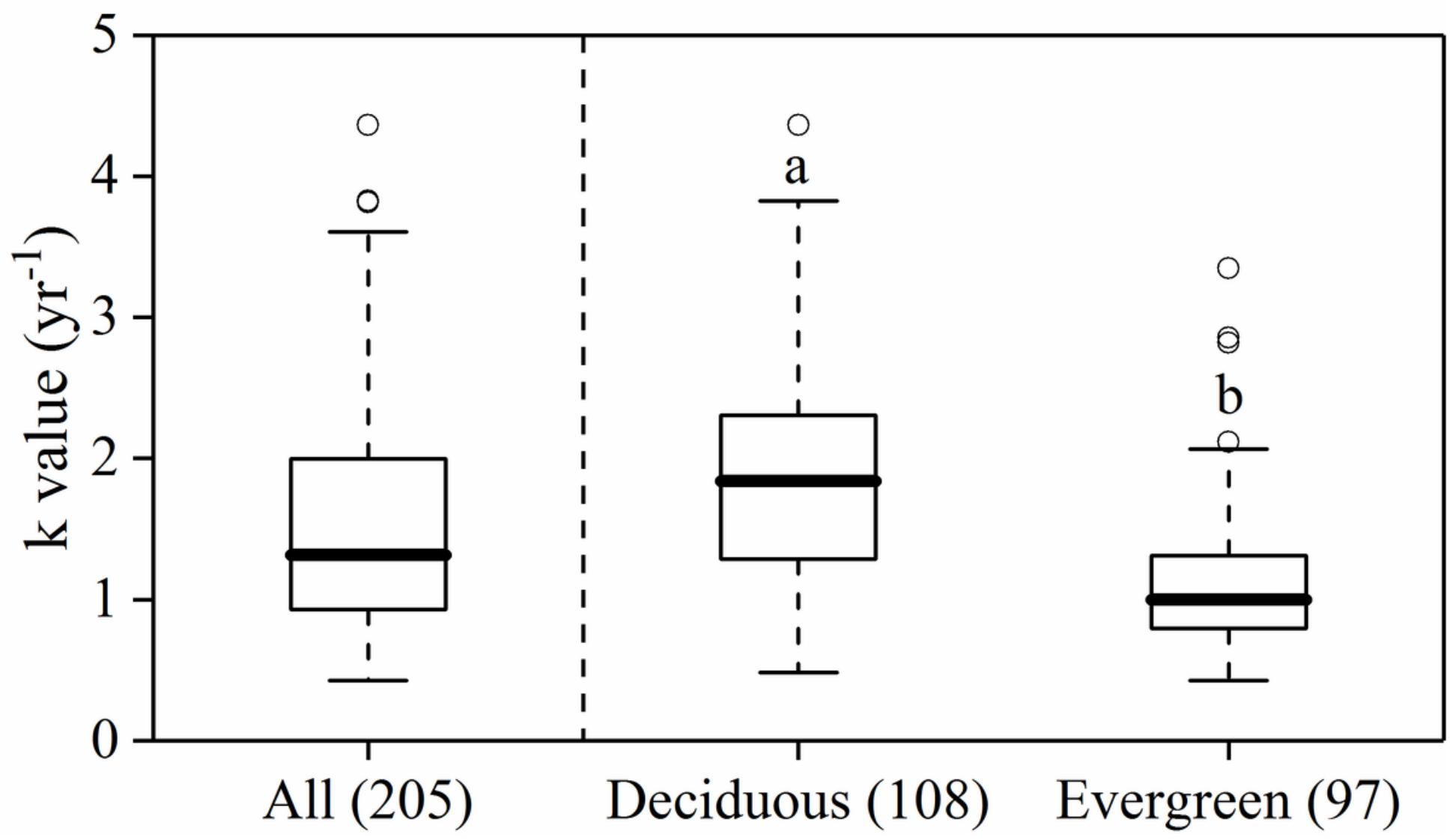

Figure 1

Comparison of litter decomposition rate constants ( $k$-value) between deciduous and evergreen species. Different lowercase letters on error bars indicate significant differences at $p<0.05$. The sample size for each functional type is shown in the bracket. 

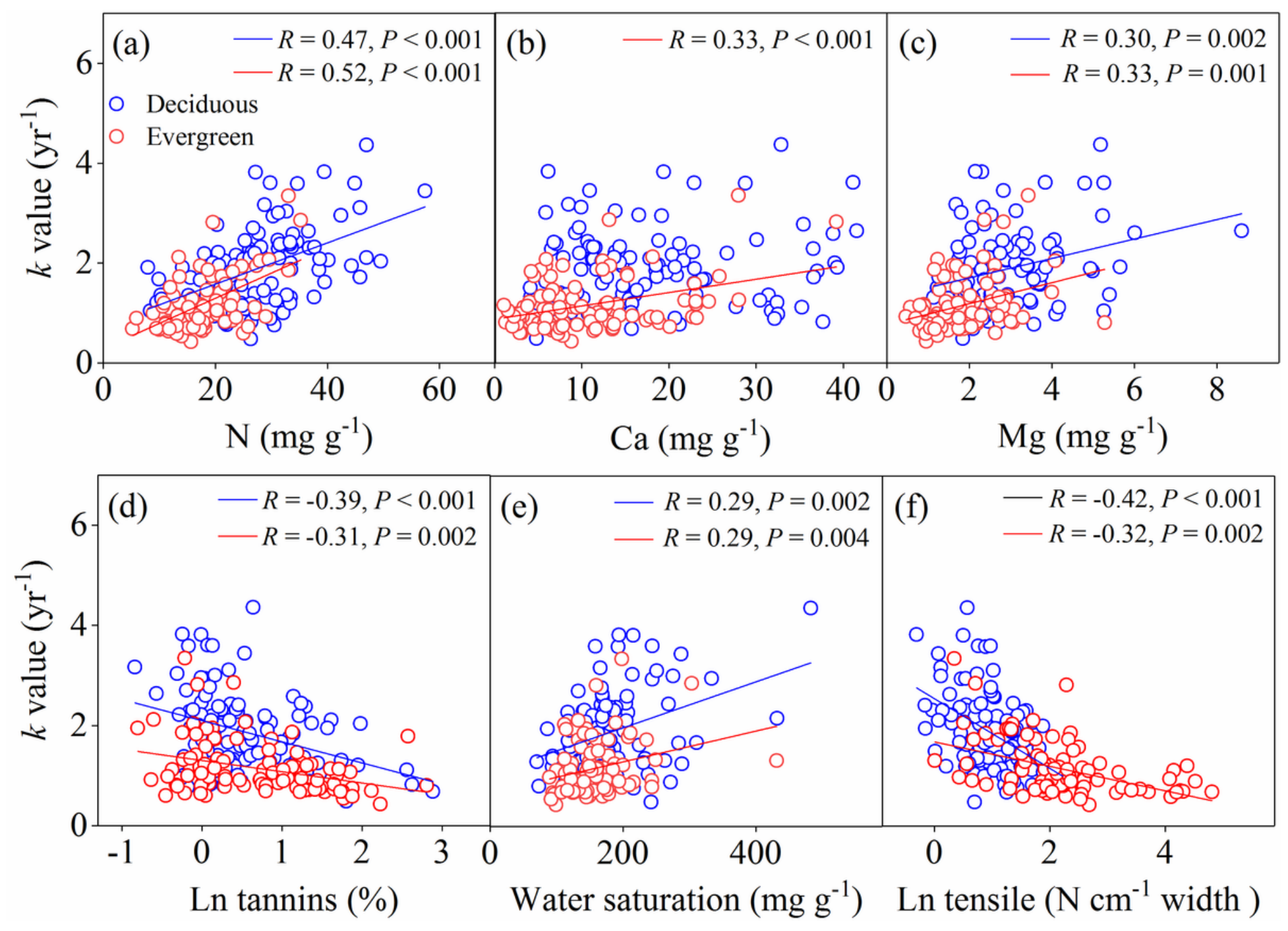

Figure 2

Relationships between litter decomposition rate constants (k-value) and some litter traits for deciduous and evergreen species. 

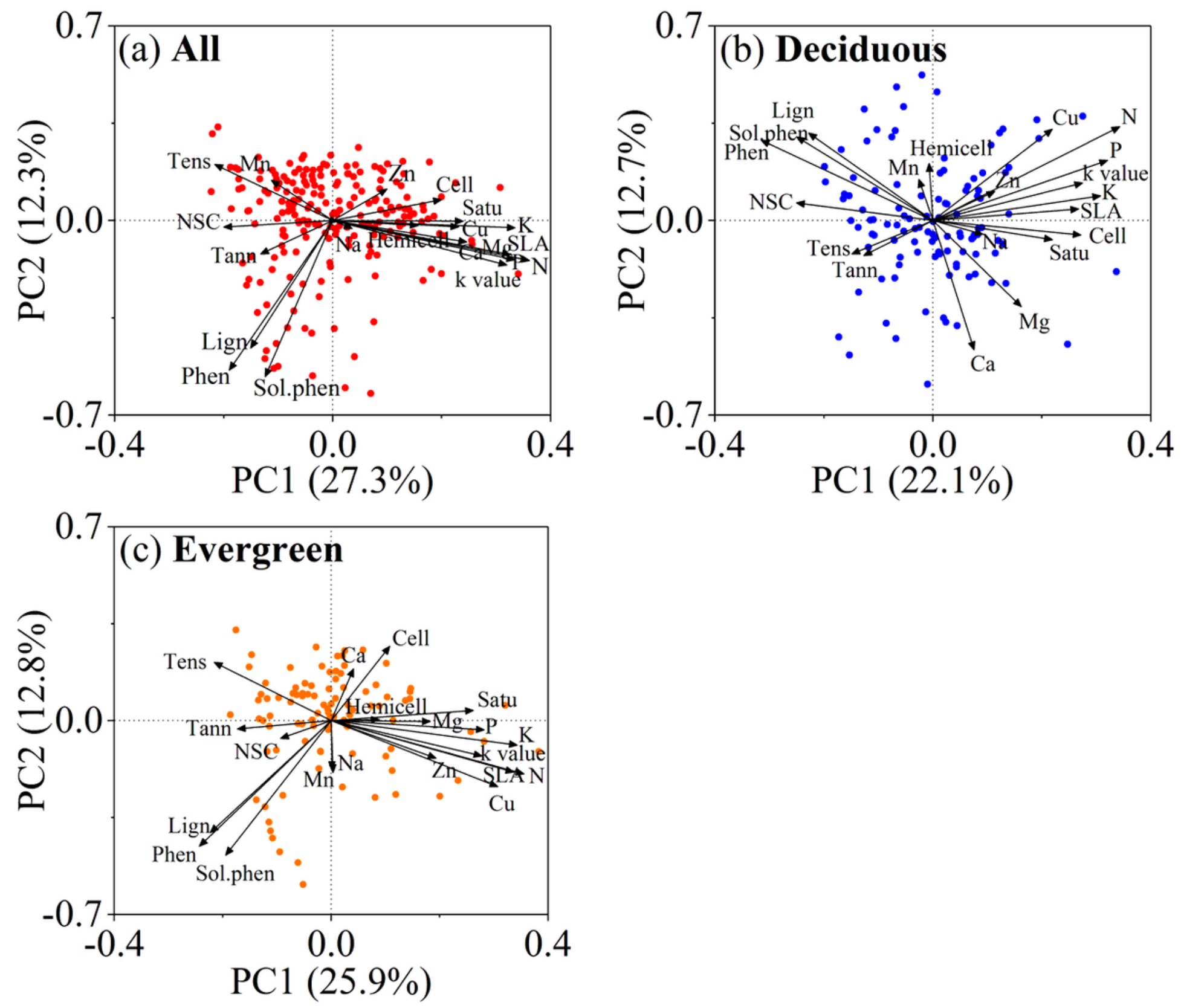

Figure 3

Principal component analysis for decomposition rate constants (k-value) and 19 initial litter traits for all species and species with different lifespan type. $\mathrm{N}$, nitrogen; $\mathrm{P}$, phosphorus; $\mathrm{K}$, potassium; $\mathrm{Ca}$, calcium; $\mathrm{Na}$, sodium; Mg, magnesium; Mn, manganese; Cu, cuprum; Zn, zinc; NSC, non-structural carbohydrates; Cell, cellulose; Hemicell, hemicellulose; Phen, phenols; Sol.phenols, soluble phenols; Lign, lignin; Tann, tannins; Satu, saturation; SLA, specific leaf area; Tens, tensile. 


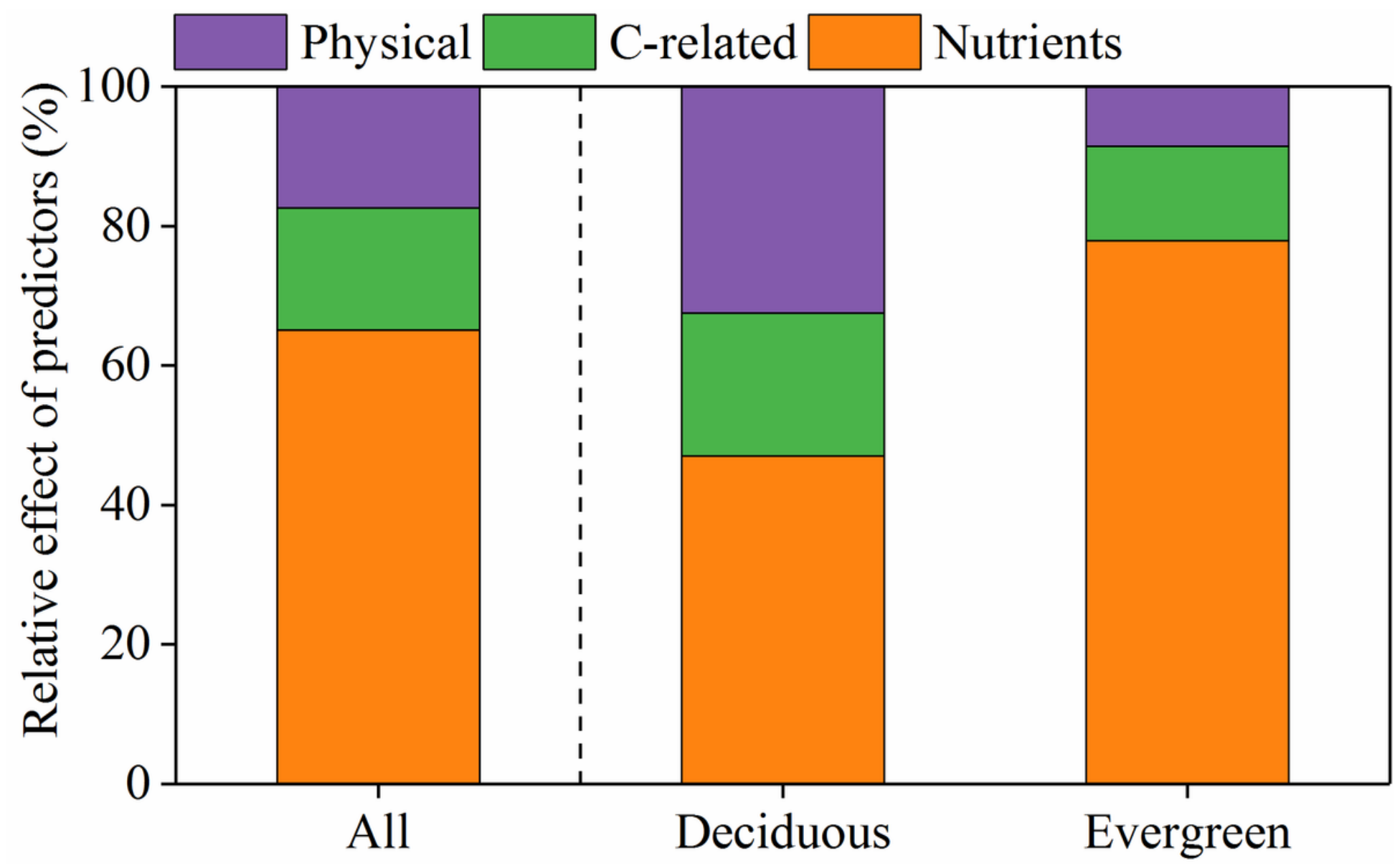

Figure 4

Hierarchical partitioning analyses for the relative importance of litter traits in predicting the decomposition rate constants ( $k$-value) for all species and species with different lifespan type.

\section{Supplementary Files}

This is a list of supplementary files associated with this preprint. Click to download.

- Supplementarymaterial.docx 